\title{
THE INCREASING OF LANGUAGE AND LOGIC MATHEMATIC ABILITY OF EARLY CHILDHOOD EDUCATION THROUGH EDUCATIVE TOOLS "PAPAN FLANEL PINTAR” IN THE KINDERGARTEN
}

\author{
Siti Wahyuningsih \\ PG PAUD FKIP UNS \\ wahyu_pgtk@yahoo.com
}

\begin{abstract}
This study aimed to improve the language and logic mathematic ability of kindergarten children in group B through the application of educational tools "Papan Flanel Pintar". The study method used Class Action Research. The study was conducted at Widya Putra Kindergarten group B which consisted of 9 boys and 11 girls. The study was done within 6 months from June to November 2010 . The instruments in this study were the results of the work sheet, the results of observations, and documentation. The aspects observed in each cycle were the activities and influence of children's ability to use educational tools "Papan Flanel Pintar" to develop children's language and logic mathematical ability. The data validation used checklists and triangulation. The data analysis technique used an interactive analysis model. The procedure of this study consisted two cycles and each cycle have two times of learning implementation in sequence; 1) action planning, 2) implementation of actions, 3) observation, and 4) reflection. The results of this study can be concluded that the application of Papan Flanel Pintar can improve the language and logic mathematic ability of children in group B Widya Putra Kindergarten, Darma Wanita, Sebelas Maret University Surakarta significantly at the stage of its development.
\end{abstract}

Keywords: language ability, logic mathematic ability, educational tools

\section{PENINGKATAN KEMAMPUAN BERBAHASA DAN LOGIKA MATEMATIKA ANAK USIA DINI MELALUI ALAT PERAGA EDUKATIF (APE) PAPAN FLANEL PINTAR DI TK}

\begin{abstract}
Abstrak: Tujuan penelitian ini adalah meningkatkan kemampuan dan perkembangan berbahasa dan logika matematika anak TK kelompok B, melalui penerapan alat permainan edukatif (APE) Papan Flanel Pintar. Metode penelitian yang digunakan adalah Penelitian Tindakan Kelas (Class Action Research). Penelitian dilakukan di TK Widya Putra kelompok B yang terdiri dari 9 anak laki-laki dan 11 anak perempuan. Pelaksanaan penelitian dilakukan dalam waktu 6 bulan mulai bulan Juni sampai November 2010. Instrumen dalam penelitian ini adalah lembar hasil unjuk kerja, hasil observasi, dan dokumentasi. Aspek yang diamati dalam setiap siklus adalah aktifitas dan pengaruh kemampuan anak dalam menggunakan APE papan flanel pintar untuk mengembangkan kemampuan berbahasa dan logika matematika anak. Validasi data yang digunakan yaitu memberi check dan triangulasi. Teknik analisis data yang digunakan adalah model analisis interaktif. Prosedur yang dilaksanakan dalam penelitian tindakan kelas ini berlangsung sampai pada dua siklus dan setiap siklusnya terdapat dua kali pelaksanaan pembelajaran dengan urutan; 1) perencanaan tindakan, 2) pelaksanaan tindakan, 3) observasi, dan 4) refleksi. Hasil penelitian tindakan kelas dapat disimpulkan bahwa penerapan Alat Peraga Edukatif Papan Flanel Pintar dapat meningkatkan kemampuan berbahasa dan logika matematika anak kelompok B1 TK Widya Putra Darma Wanita Universitas Sebelas Maret Surakarta secara signifikan pada tahap perkembangannya.
\end{abstract}

Kata Kunci: kemampuan berbahasa, logika matematika, Alat Peraga Edukatif (APE) 


\section{PENDAHULUAN}

Pendidikan di Taman Kanak-kanak bertujuan untuk membantu anak meletakkan dasar ke arah perkembangan sikap, pengetahuan, ketrampilan dan kreativitas yang diperlukan oleh anak dalam menyesuaikan diri dengan lingkungannya dan untuk pertumbuhan dan perkembangan selanjutnya.

Keberhasilan pelaksanaan suatu program pendidikan untuk Anak Usia Dini sangat tergantung pada pengelolaan sumber belajar. Seorang guru hendaknya mempunyai kemahiran dalam mengelola sumber belajar untuk pembelajaran Anak Usia Dini (AUD), agar pelaksanaan program pembelajaran dapat berjalan tidak saja efektif tetapi juga menyenangkan dan sesuai karakter peserta didik.

Pada tahun 1972 Dewan Nasional Indonesia untuk kesejahteraan sosial memperkenalkan istilah Alat Peraga Edukatif (APE). APE merupakan perkembangan dari proyek pembuat buku keluarga dan balita yang dikelola kantor Menteri Urusan Peranan Wanita. Karena keberhasilan proyek tersebut APE digunakan wilayah Indonesia melalui program BKKBN dan Ibu-ibu PKK. Alat Peraga Edukatif (APE) adalah salah satu sumber belajar yang khas dalam pembelajaran anak usia dini, Dunia anak tidak dapat dilepaskan dari bergerak, beraktifitas dan hampir semua kegiatan dan aktifitas anak menggunakan alat bantu bermain. Oleh karena itu, alat bantu atau alat peraga ini tidak dapat dipisahkan dari kebutuhan anak.

Menurut Anggani Sudono (2000) dalam buku Sumber Belajar dan Alat Permainan, alat permainan yang sesuai dengan kebutuhan anak akan mengacu pada perkembangan mereka dan merupakan dorongan atau tantangan yang tidak membosankan [3]. Alat permainan dibuat mengacu pada tujuan pembelajaran dan disesuaikan dengan usia dan karakteristik anak yang akan bermain.

Pengertian alat permainan dapat sekaligus dimanfaatkan untuk mengembangkan beberapa aspek perkembangan anak. Oleh karenanya sering dijumpai di lembaga pendidikan usia dini dan taman kanak-kanak mencantumkan berbagai alat permainan di dalam program kegiatan hariannya.

Alat permainan edukatif dapat difungsikan secara multiguna, sekalipun masing-masing alat memiliki kekhususan, untuk mengembangkan aspek perkembangan tertentu, tidak jarang satu alat dapat meningkatkan lebih dari satu aspek perkembangan. Dan berfungsi untuk menumbuhkembangkan potensi kecerdasan anak secara menyeluruh dan terpadu.

Sebagian alat permainan edukatif dikenal sebagi alat manipulatif. Manipulatif berarti menggunakan secara terampil, dapt diperlakukan menurut kehendak dan pemikiran serta imajinatif anak. Belajar mengelolanya dengan baik akan memberi kepuasan dan manfaat bagi anak, ia juga merasa dapat menguasai (mastering) permainannya. Pada intinya anak benar-benar memahami konsep yang terkandung dalam alat permainan edukatif itu. Kesemuanya terjadi tanpa paksaan, yang dilakukan anak didasarkan motivasi yang muncul dalam dirinya.

Syarat-syarat permainan edukatif diantaranya adalah: (1) dapat digunakan dalam berbagai cara, yakni dapat dimainkan dengan bermacam tujuan, manfaat dan menjadi bermacam bentuk, (2) ditujukan terutama untuk anak usia pra sekolah dan berfungsi mengembangkan berbagai aspek perkembangan kecerdasan serta motorik anak, (3) segi keamanan sangat diperhatikan 
baik bentuk, bahan, teknis, pembuatan maupun penggunaan cat, (4) membuat anak terlibat secara aktif, (5) sifatnya konstruktif, (6) sesuai dengan tahapan perkembangan dan kebutuhan anak, (7) memotivasi anak untuk bereksplorasi dan berkreasi.

Permainan edukatif selalu dirancang dengan pemikiran yang dalam agar melalui bermain alat tersebut, anak mampu mengembangkan penalarannya. Biasanya tiga variabel yang terpenting dalam alat permainan edukatif yaitu ukuran, bentuk dan warnanya dibuat dengan rancangan tertentu, sehingga bila anak salah mengerjakan akan segera menyadarinya dan membetulkannya. Tetapi sebaliknya bila alat tersebut menimbulkan frustasi atau kemarahan yang tidak terkendali, maka jelaslah alat tersebut sulit bagi anak, dan sebaliknya pula alat tersebut disimpan untuk digunakan pada kesempatan lain.

Alat sumber pelajaran sebagai salah satu komponen strategi pembelajran adalah bahan termasuk juga alat permainan untuk memberikan informasi maupun berbagai ketrampilan kepada murid maupun guru. Sedangkan alat permainan adalah semua alat bermain yang digunakan oleh anak untuk memenuhi naluri bermainnya dan memiliki berbagai macam sifat seperti, mengelompokkan, memadukan, merangkai, menyusun pola, menyempurnakan suatu disain, dan membentuk.

Melihat fenomena yang ada, guru sebagai fasilitator menfasilitasi proses perkembangan anak melalui kegiatan bermain sambil belajar dengan alat permainan yang menyenangkan yang dapat membantu mengembangkan berbagai potensi yang dimiliki anak.

Apa yang harus guru lakukan sebelum memperkenalkan permainan kepada murid? Tentunya harus dicoba dulu agar guru tahu dimana letak kesulitan, berapa lama waktu yang dibutuhkan, berapa orang yang dapat memainkan permainan tersebut dan media apa yang dibutuhkan. Murid diberi pemahaman tentang penggunaannya dan bertanggung jawab terhadap alat yang dipakai.

Setiap orang sejak bayi hingga dewasa membutuhkan aktifitas yang menyenangkan. Bagi anak usia dini, bermain sama maknanya dengan belajar dan bekerja pada orang dewasa. Melalui aktifitas anak memperoleh pengalaman yang mengandung aspek perkembangan fisik, kognitif, sosial dan emosi.

Melalui aktifitas bermain, anak menggunakan alat bantu atau alat peraga, anak dirangsang untuk berkembang secara umum baik perkembangan berpikir, bergerak maupun bersosialisasi.

Anak belajar melalui aktifitas dalam sebuah permainan, Mereka belajar melalui inderanya dan hubungan fisik dengan lingkungannya. Kegiatan bermain sehari-hari tersebut merupakan pendidikan yang dapat menumbuhkan kreatifitas sekaligus memupuk dan mengembangkan sikap kerja sama, sportifitas, sosialaisasi, menahan diri, imajinasi, intelegensi, responsif, tenggang rasa dan lain-lain. Kegiatan inilah yang memungkinkan anak dapat mengisi hari-harinya dengan penuh arti. Anak menjadi gembira penuh percaya diri, konsep dirinya tumbuh semakin positif dan akhirnya terus berusaha mengembangakan berbagai potensi yang dimilikinya secara lebih optimal.

Dunia di sekeliling kita penuh oleh kegiatan matematika, kenyataannya matematika telah menjadi bagian yang penting dalam berbagai aktivitas kehidupan manusia, bahkan telah terjadi pada tahun awal kehidupan seorang anak, jauh sebelum anak memahami simbolsimbol abstrak dan rumus-rumus. Anak akan berbahasa untuk menemukan matematika dalam 
berbagai benda yang dilihat dan disentuhnya, misalnya seorang anak memperoleh pengalaman pertama yang berhubungan dengan bentuk pada saat menggelindingkan bola serta memegang cangkir minumnya. Bimbingan dan arahan yang diberikan orang tua kepada anaknya dapat membantu mereka dalam memahami, kemudian membehasakan konsep matematika, seperti mengelompokkan, membandingkan, menyusun urutan dan berhitung.

Berbahasa dan matematika akan membantu anak untuk menyadari dunia sekelilingnya dan menemukan makna terhadap dunia fisik yang ditemuinya setiap hari. Melalui kegitan pengembangan bahasa dan matematika, anak belajar berkomunikasi untuk memahami angka dan bentuk. Anak belajar mengemukakan alasan, menghubungkan gagasan dan berpikir logis. Kemampuan bahasa dan matematika lebih dari sekedar kegiatan menyelesaikan soal-soal dan operasi bilangan yang terlalu rumit. Namun secara lebih luas membantu untuk berkomunikasi dan berpikir mendalam tentang berbagai hubungan dan pola dalam segala hal yang dilakukan.

Psikolog pendidikan dari Fakultas Psikologi UI, Gagan Hartana, M.Psi mengatakan, kecerdasan berbahasa dan matematika diartikan kemampuan menyelesaikan masalah yang berkaitan dengan kebutuhan berbahasa dan matematika sebagai solusinya. Misalnya, saat menanam kecambah kacang hijau, dihari pertama anak melihat kecambah tumbuh, anak dengan kecerdasan bahasa dan matematika akan menebak kecambah akan tumbuh lebih tinggi tanpa melihat kelanjutan pertumbuhannya. Anak menghadapi problem yang dasar penyelesaiannya membutuhkan kemampuan berbahasa dan logika matematika untuk mampu berpikir abstrak.

Gardner (1999) memaparkan, ciri anak cerdas matematika, pada usia balita, anak gemar bereksplorasi untuk memenuhi rasa ingin tahunya seperti menjelajah setiap sudut, mengamati benda-benda yang unik baginya [1]. Selain itu, anak juga hobi mengutakutik benda serta melakukan uji coba. Seperti, "bagaimana jika kakiku masuk ke dalam ember penuh berisi air atau penasaran menyusun Puzzle?"

Belajar matematika tak harus serius, namun bisa menyisipkannya dalam pengalaman sehari-hari dari sisi linguistiknya. Berikan pemahaman konsep matematika seperti mengajarkan anak pemahaman kuantitas,. Tanyakan padanya es krim A dengan $\mathrm{B}$ mana yang ukurannya lebih besar. Yang penting, anak diberikan stimulasi yang memadai. Saat anak sudah bisa berkomunikasi bisa memasukkan informasi seperti pengenalan konsep perbandingan lebih besar, lebih kecil, dan sebagainya. Angka hanyalah simbol, sebaiknya anak memahami proses dibalik angka.

Ketika mengenalkan dan menanyakan pada anak si A berlari lebih kencang dibanding $\mathrm{B}$ atau si $\mathrm{B}$ lebih tinggi dibandingkan $\mathrm{A}$, atau tas a lebih berat dibandingkan tas $b$, sebenarnya sudah mengajarkan pada anak konsep kecepatan, panjang dalam meter atau berat dalam kologram. Dengan demikian, fungsi kecerdasan bahasa dan matematikanya sudah aktif. Sejauh anak bisa memahami itu, bisa diberikan stimulasi yang lebih tinggi.

Lebih lanjut Gardner mengatakan, kecerdasan berbahasa dan matematika bisa mengembangkan kecerdasan lainnya. "Meski tidak berkaitan secara langsung, namun fungsinya bisa membantu anak menyelesaikan masalah menggunakan dimensi bahasa dan matematika". Perkembangan kemampuan berbahasa dan logika matematika melahirkan pemikiran sistematis pada anak. 
Pada dasarnya setiap anak dianugerahi kecerdasan bahasa dan matematika logis. Gardner mendefinisikan kecerdasan linguistik dan matematis logis sebagai kemampuan penalaran ilmiah, perhitungan secara matematis, berpikir logis, penalaran induktif/deduktif, dan ketajaman pola-pola abstrak serta hubungan-hubungan. Dapat diartikan juga sebagai kemampuan menyelesaikan masalah yang berkaitan dengan kebutuhan bahasa dan matematika sebagai solusinya. Anak dengan kemampuan ini akan senang dengan rumus dan pola-pola abstrak. Tidak hanya pada bilangan matematika, tetapi juga meningkatkan pada kegiatan yang bersifat analitis dan konseptual. Menurut Gardner ada kaitan antara kecerdasan matematika dan kecerdasan linguistik. Pada kemampuan matematika, anak menganalisa atau menjabarkan alasan logis, serta kemampuan mengkonstruksi solusi dari persoalan yang timbul. Kecerdasan linguistik diperlukan untuk merunutkan dan menjabarkannya dalam bentuk bahasa.

Bagaimana kita merangsang kecerdasan berbahasa dan matematis logis anak sejak usia dini? Bagaimana kita menanamkan konsep matematis sejak dini? Kita bisa mengenalkan pertama kali pemahaman konsep matematika sejak usia dini dari lingkungan sekitar kita dan pengalaman sehari-hari anak serta memberikan stimulasi yang mendukung. Tentu saja hal ini dilakukan tanpa paksaan dan tekanan, dan melalui permainanpermainan. Dalam pendidikan anak, peran orangtua tak tergantikan dan rumah merupakan basis utama pendidikan anak. Banyak permainan eksplorasi yang bisa mengasah kemampuan logika matematika anak, namun tentu hal ini harus disesuaikan dengan usia anak. Saat anak balita bermain pasir, anak sesungguhnya sedang menghidupkan otot tangannya yang melatih motorik halusnya sehingga kelak anak mampu memegang pensil, menggambar dan lain-lain. Dengan bermain pasir anak sesungguhnya belajar estimasi dengan menuang atau menakar yang kelak semua itu ada dalam cara menyampaikan secara verbal dan berlogika matematika.

Anak dengan kedua kemampuan ini akan senang asyik dengan berkatakata dan mempelajari rumus dan polapola abstrak. Tapi tak hanya pada bilangan matematika, juga meningkat pada kegiatan berbahasa untuk menyampaikan kegiatan bersifat analitis, dan konseptual, semua ini membutuhkan keterampilan berbahasa, dan hal ini ditegaskan Howard Gardner (1993) dalam bukunya Multiple Intelegences, The Theory in Practice, bahwa ada kaitan logika matematika dengan kecerdasan linguistik [2]. Pada kemampuan matematika anak menganalisa atau menjabarkan alasan logis, serta kemampuan mengkonstruksi solusi dari persoalan yang timbul. Kecerdasan linguistic diperlukan untuk merunutkan dan menjabarkannya dalam bentuk bahasa. Berdasarkan uraian yang dikemukakan di atas, berbahasa dan matematika merupakan sarana yang penting dalam rangka memecahkan berbagai maslah, untuk itu bahasa dan matematika merupakan kegiatan yang akan banyak dilalui anak dalam kehidupannya.

Sebagaimana diketahui bahwa bermain merupakan filosofi dasar yang harus melandasi setiap praktek pendidikan anak usia dini. Bermain merupakan kegiatan yang tidak dapat dipisahkan dari dunia anak. Melalui bermain anak membangun konsep dan pemahaman yang menyeluruh tentang dunia sekelilingnya. Bermain merupakan kegiatan yang dilakukan secara sukarela, timbul dari dorongan 
dalam diri anak, sehingga memungkinkan keterlibatan anak dalam setiap permainan secara aktif dan bermakna.

Alat Peraga Edukatif dapat difungsikan secara multiguna, sekalipun masing-masing alat memiliki kekhususan, dalam artian mengembangkan aspek perkembangan tertentu pada anak, tidak jarang satu alat dapat meningkatkan lebih dari satu aspek perkembangan, dan berfungsi untuk menumbuh kembangkan potensi kecerdasan anak secara menyeluruh dan terpadu.

Lembaga pendidikan, dalam hal ini salah satunya adalah Taman Kanakkanak merupakan salah satu lembaga yang sesuai dalam rangka menumbuhkan dan mengembangkan berbagai potensi anak sejak dini melalui berbagai aktifitas bermain dengan alat peraga yang menyenangkan. Penulis mencoba membuat sebuah alat peraga kegiatan belajar yang dinamakan Papan Flanel Pintar. APE tersebut pada kesempatan ini, difungsikan untuk meningkatkan perkembangan kecerdasan berbahasa dan kecerdasan logika matematika pada peserta didik.

\section{METODE PENELITIAN}

Penelitian tindakan kelas dilakukan di Taman Kanak-kanak Widya Putra Darma Wanita Universitas Sebelas Maret Surakarta pada kelompok B. Penelitian ini dilaksanakan selama 3 bulan pada semester ganjil, yaitu bulan Agustus, September, Oktober, tahun 2010. Subjek penelitian ini adalah anakanak kelompok B1 yang berjumlah 20 anak tahun pelajaran 2009/2010. Alamat TK Widya Putra berada di Jalan Pembangunan IV/No. 82 Perum Dosen UNS Jati - Jaten Karanganyar.

Teknik pengumpulan data menggunakan 3 cara yaitu:

1. Dokumentasi

Teknik ini digunakan untuk mengumpulkan data yang berupa foto- toto dokumen foto dari penerapan APE Papan Flanel Pintar pada siklus I, II sampai dengan siklus III. Kegiatan ini selain untuk memperoleh dokumen dan arsip, juga mendapatkan gambaran secara lengkap tentang perkembangan anak-anak pada aspek peningkatan kemampuan berbahasa dan logika matematikanya.

2. Observasi

Observasi yang dilakukan pada penelitian ini adalah observasi langsung. Observasi dilakukan pada saat kegiatan pembelajaran pada tema diri sendiri, kebutuhanku dan lingkungan anak-anak Kelompok B TK Widya Putra Darma Wanita UNS untuk mengetahui peningkatan kemampuan anak-anak pada aspek tersebut di atas.

3. Tes

Jenis tes yang dilakukan adalah tes unjuk kerja, dan tes dilakukan pada setiap akhir pelaksanaan siklus.

Teknik analisis data dilakukan melalui triangulasi, yaitu data diharapkan dapat memberikan informasi yang lebih tepat, yaitu:

1. Peneliti lakukan dengan diskusi silang dengan para guru/kolaborator, yaitu temuantemuan selama observasi kita cari titik temu dari masing-masing pandangan temuan kita.

2. Hasil observasi yang telah diskusikan, kemudian dicari rujukan dari hasil studi pustaka atau literatur yang mendukung materi tersebut.

3. Hasil kajian dari para pakar terkait dengan temuan-temuan peneliti bersama kolaborator dari hasil observasi selama melakukan penelitianKkemudian dari data yang telah dikumpulkan itu diambil keputusan dan kesimpulan.

Prosedur rencana tindakan dalam penelitian ini adalah sebagai berikut:

1. Siklus I 
a. Perencanaan I

Pada tahap ini dilakukan penyusunan Rencana Pelaksanaan Pembelajaran (RPP), tema Diri sendiri dengan indikator Bahasa: anak dapat menghubungkan tulisan sederhana dengan simbol yang melambangkannya. Sedangkan indicator kemampuan dasar kognitif atau logika matematika adalah menunjuk dan mencari sebanyakbanyaknya benda, hewan, tanaman yang mempunyai warna, bentuk, ukuran atau menurut ciri-ciri tertentu.

Rencana yang telah dibuat kemudian diterapkan dalam proses kegiatan inti pembelajaran dan pelaksanaan tindakan diwujudkan dalam langkah-langkah: 1) anak dibentuk dalam kelompok yang beranggota 4 anak, 2) papan flanel dibuka diatas meja atau di lantai, 3) guru memberi bimbingan pada anak-anak yang bekerja dalam kelompok sesuai dengan uruturutan: (a) anak-anak menempel bendabenda yang tersedia kemudian menyebutkan, (b) anak-anak merangkai huruf pada salah satu benda, (c) anakanak secara bersama-sama mempresentasikan hasil bongkar pasang APE papan flanel pintar tersebut.

b. Pengamatan

Pengamatan berupa kegiatan pemantauan, pencatatan, serta mendokumentasikan semua kegiatan anak-anak yang bekerja di dalam kelompok selama pelaksanaan pembelajaran yaitu: a) bagaimana anak mencari benda, b) bagaimana anak melakukan bongkar pasang, c) bagaimana anak mencari huruf-huruf untuk dipasangkan pada salah satu benda, d) bagaimana anak-anak menceriterakan/ mempresentasikan hasil memasang-masangkan benda-benda, huruf dan angka. Data yang diperoleh dari kegiatan observasi dianalisis guna mengetahui kelebihan dan kekurangan dari tindakan yang telah dilakukan.

c. Refleksi
Refleksi berarti penilaian dan pengkajian terhadap hasil evaluasi data yang berkaitan dengan pencapaian anak pada siklus I. Evaluasi digunakan untuk mengetahui kekurangan-kekurangan dari tindakan siklus I, dimungkinkan hasilnya ada peningkatan yaitu lebih dari $51 \%$ anak dapat mencapai ketuntasan, sehingga kekurangan pada siklus I ini untuk dirancang pada siklus II sehingga kita dapat memperbaikinya pada siklus II.

\section{HASIL DAN PEMBAHASAN}

Hasil penerapan APE Papan Flanel Pintar dalam tema Tanaman dengan indikator bahasa anak dapat menghubungkan tulisan sederhana dengan simbol yang melambangkannya. Sedangkan indikator kemampuan dasar kognitif atau logika matematikanya adalah menunjuk dan mencari sebanyakbanyaknya benda, hewan, tanaman yang mempunyai warna, bentuk, ukuran atau menurut ciri-ciri tertentu.

Tabel 1. Data Hasil Observasi Aktivitas Anak Yang Relevan Dengan Kegiatan Pembelajaran Pada Siklus I

\begin{tabular}{|c|c|c|c|}
\hline \multirow[b]{2}{*}{ No } & \multirow[b]{2}{*}{ Indikator } & \multicolumn{2}{|c|}{ Ketercapaian } \\
\hline & & $\begin{array}{c}\text { Kondisi } \\
\text { Awal }\end{array}$ & $\underset{\text { I }}{\text { Siklus }}$ \\
\hline 1. & $\begin{array}{l}\text { Dalam kelompok, } \\
\text { anak dapat } \\
\text { bekerjasama }\end{array}$ & $40 \%$ & $51 \%$ \\
\hline 2. & $\begin{array}{l}\text { Ketepatan dalam } \\
\text { menempel benda- } \\
\text { benda yang dipilih } \\
\text { sesuai dengan Tema } \\
\text { Tanaman }\end{array}$ & $45 \%$ & $61 \%$ \\
\hline 3. & $\begin{array}{lr}\text { Ketepatan } & \\
\text { merangkai } & \text { huruf } \\
\text { sesuai } & \text { dengan } \\
\text { bendanya } & \end{array}$ & $46 \%$ & $65 \%$ \\
\hline \multirow[t]{2}{*}{4.} & $\begin{array}{l}\text { Ketepatan } \\
\text { menyebutkan nama- } \\
\text { nama tanaman }\end{array}$ & $50 \%$ & $57 \%$ \\
\hline & & \multicolumn{2}{|c|}{ Ketercapaian } \\
\hline No & Indikator & $\begin{array}{c}\text { Kondisi } \\
\text { Awal }\end{array}$ & $\begin{array}{c}\text { Siklus } \\
\text { I }\end{array}$ \\
\hline 5. & $\begin{array}{l}\text { Kelancaran dalam } \\
\text { melaporkan hasil } \\
\text { kerja kelompok }\end{array}$ & $40 \%$ & $55 \%$ \\
\hline
\end{tabular}


Berdasarkan tabel 1 di atas, terlihat bahwa aktivitas anak dalam penerapan APE Papan Flanel Pintar dengan tujuan untuk mengembangkan kemampuan bahasa dan kemampuan logika matematika atau kognitif mengalami peningkatan jika dibandingkan pada kondisi awal rata-rata sebesar dari $44.2 \%$ pada siklus I menjadi $57.8 \%$

Selanjutnya data aktivitas anakanak yang kurang relevan dengan kegiatan pembelajaran terlihat pada tabel 2 berikut ini:

Tabel 2. Data Aktivitas Anak-Anak yang Kurang Relevan Dengan Kegiatan Pembelajaran Pada Siklus I

\begin{tabular}{|c|c|c|c|}
\hline \multirow[b]{2}{*}{ No } & \multirow[b]{2}{*}{ Indikator } & \multicolumn{2}{|c|}{ Ketercapaian } \\
\hline & & $\begin{array}{c}\text { Kondisi } \\
\text { Awal }\end{array}$ & $\underset{\text { I }}{\text { Siklus }}$ \\
\hline 1. & $\begin{array}{lr}\text { Masih } & \text { punya } \\
\text { keinginan } & \text { kerja } \\
\text { sendiri } & \\
\end{array}$ & $60 \%$ & $49 \%$ \\
\hline 2. & $\begin{array}{l}\text { Masih } \\
\text { memunculkan sifat } \\
\text { egoisnya }\end{array}$ & $55 \%$ & $39 \%$ \\
\hline 3. & 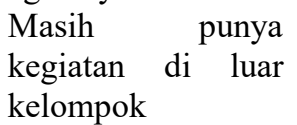 & $54 \%$ & $35 \%$ \\
\hline 4. & $\begin{array}{l}\text { Masih mengganggu } \\
\text { kegiatan di dalam/ } \\
\text { luar kelompok }\end{array}$ & $50 \%$ & $43 \%$ \\
\hline 5. & $\begin{array}{l}\text { Masih } \\
\text { menunjukkan tidak } \\
\text { mau ikut } \\
\text { melaporkan hasil }\end{array}$ & $60 \%$ & $45 \%$ \\
\hline Jun & & $55.8 \%$ & $42.2 \%$ \\
\hline
\end{tabular}

Berdasarkan tabel 2 di atas terlihat bahwa aktivitas anak-anak yang kurang relevan dengan kegiatan pembelajaran pada siklus 1 mengalami penurunan dibandingkan dengan kondisi awal yaitu sebesar (kondisi awal 55.8\%) dan (hasil siklus I $42.2 \%$ ).

Hasil Penerapan APE Papan Flanel Pintar dalam Pelaksanaan Pembelajaran dengan Tema Buah-buahan dengan indikator Bahasa: adalah melakukan bongkar pasang dari beberapa huruf sehingga dapat membedakan kata-kata yang mempunyai suku kata awal yang sama (misal: awan-angsa) dan suku kata akhir yang sama (papi-sapi). Sedangkan indikator kemampuan dasar kognitif atau logika matematika: adalah menyusun benda dari besarkecil atau sebaliknya.

Tabel 3. Data Hasil Observasi Aktivitas Anak yang Relevan Dengan Kegiatan Pembelajaran Pada Siklus II

\begin{tabular}{|c|c|c|c|}
\hline \multirow[b]{2}{*}{ No } & \multirow[b]{2}{*}{ Indikator } & \multicolumn{2}{|c|}{ Ketercapaian } \\
\hline & & $\begin{array}{c}\text { Kondisi } \\
\text { Awal }\end{array}$ & $\underset{\text { I }}{\text { Siklus }}$ \\
\hline 1. & $\begin{array}{l}\text { Dalam kelompok, } \\
\text { anak dapat bekerja } \\
\text { sama }\end{array}$ & $51 \%$ & $71 \%$ \\
\hline 2. & $\begin{array}{l}\text { Ketepatan dalam } \\
\text { menempel benda- } \\
\text { benda yang dipilih } \\
\text { sesuai dengan } \\
\text { Tema Buah-buahan }\end{array}$ & $61 \%$ & $76 \%$ \\
\hline 3. & $\begin{array}{lr}\text { Ketepatan } & \\
\text { merangkai } & \text { huruf } \\
\text { sesuai } & \text { dengan } \\
\text { bendanya } & \end{array}$ & $65 \%$ & $76 \%$ \\
\hline 4. & $\begin{array}{l}\text { Ketepatan } \\
\text { menyebutkan } \\
\text { nama-nama buah- } \\
\text { buahan }\end{array}$ & $57 \%$ & $71 \%$ \\
\hline 5. & $\begin{array}{l}\text { Kelancaran dalam } \\
\text { melaporkan hasil } \\
\text { kerja kelompok }\end{array}$ & $51 \%$ & $71 \%$ \\
\hline Jun & lah & $57 \%$ & $73.2 \%$ \\
\hline
\end{tabular}

Berdasarkan tabel 3 di atas, terlihat bahwa aktivitas anak-anak dalam penerapan APE Papan Flanel Pintar dengan tujuan untuk mengembangkan kemampuan bahasa dan kemampuan logika matematika atau kognitif. Berdasarkan indicator perkembangan bahasa dan kemampuan logika matematika, pada siklus II ini anak-anak mengalami peningkatan yang signifikan jika dibandingkan pada hasil siklus I, hasil presentase peningkatannya dari $57.8 \%$ menjadi $73.2 \%$.

Selanjutnya data aktivitas anakanak yang kurang relevan dengan kegiatan pembelajaran terlihat pada tabel 4 berikut ini: 
Tabel 4. Data Aktivitas Anak-anak yang

Kurang Relevan Dengan Kegiatan

Pembelajaran Pada Siklus Ke-II

\begin{tabular}{|c|c|c|c|}
\hline \multirow[b]{2}{*}{ No } & \multirow[b]{2}{*}{ Indikator } & \multicolumn{2}{|c|}{ Ketercapaian } \\
\hline & & $\begin{array}{c}\text { Kondisi } \\
\text { Awal }\end{array}$ & $\begin{array}{c}\text { Siklus } \\
\text { I }\end{array}$ \\
\hline 1. & $\begin{array}{lr}\text { Masih } & \text { punya } \\
\text { keinginan } & \text { kerja } \\
\text { sendiri } & \end{array}$ & $49 \%$ & $30 \%$ \\
\hline 2. & $\begin{array}{l}\text { Masih } \\
\text { memunculkan sifat } \\
\text { egoisnya }\end{array}$ & $39 \%$ & $24 \%$ \\
\hline 3. & $\begin{array}{lr}\text { Masih } & \text { punya } \\
\text { kegiatan } & \text { di } \\
\text { kelompok } & \\
\end{array}$ & $35 \%$ & $24 \%$ \\
\hline 4. & $\begin{array}{l}\text { Masih mengganggu } \\
\text { kegiatan di } \\
\text { dalam/luar kel. }\end{array}$ & $43 \%$ & $29 \%$ \\
\hline 5. & $\begin{array}{l}\text { Masih } \\
\text { menunjukkan tidak } \\
\text { mau ikut } \\
\text { melaporkan hasil }\end{array}$ & $45 \%$ & $27 \%$ \\
\hline Jun & ah & $42 \%$ & $26.8 \%$ \\
\hline
\end{tabular}

Berdasarkan tabel 4 di atas terlihat bahwa aktivitas anak-anak yang kurang relevan dengan kegiatan pembelajaran pada siklus 1I mengalami penurunan dibandingkan dengan hasil pada siklus I yaitu sebesar (hasil siklus I 42.2\%) dan (hasil siklus II $26.8 \%$ ).

Hasil Penerapan APE Papan Flanel Pintar pada pelaksanaan pembelajaran, dengan Tema Bunga dengan indikator Bahasa: mendengarkan dan menceriterakan bunga-bunga, angka dan huruf yang dipasang. Sedangkan indikator kemampuan dasar kognitif atau logika matematika: adalah membuat urutan bilangan dari 1-10 dengan benda-benda tersebut di atas.

Tabel 5. Data Hasil Observasi Aktivitas Anak yang Relevan Dengan Kegiatan Pembelajaran Pada Siklus Ke-III

\begin{tabular}{|c|c|c|c|}
\hline \multirow[b]{2}{*}{ No } & \multirow[b]{2}{*}{ Indikator } & \multicolumn{2}{|c|}{ Ketercapaian } \\
\hline & & $\begin{array}{c}\text { Kondisi } \\
\text { Awal }\end{array}$ & $\begin{array}{c}\text { Siklus } \\
\text { I }\end{array}$ \\
\hline 1. & $\begin{array}{l}\text { Dalam kelompok, } \\
\text { anak dapat bekerja } \\
\text { sama }\end{array}$ & $71 \%$ & $85 \%$ \\
\hline 2. & $\begin{array}{l}\text { Ketepatan dalam } \\
\text { menempel benda- }\end{array}$ & $76 \%$ & $88 \%$ \\
\hline
\end{tabular}

benda yang dipilih

sesuai dengan

Tema Bunga

3. Ketepatan $76 \% \quad 86 \%$ merangkai huruf sesuai dengan bendanya

4. Ketepatan $\quad 71 \% \quad 90 \%$ menyebutkan nama-nama bunga

5. Kelancaran dalam $73 \% \quad 85 \%$ melaporkan hasil kerja kelompk

Jumlah $73.2 \% \quad 86.8 \%$

Berdasarkan tabel 5 di atas, terlihat bahwa aktivitas anak-anak (sebanyak 20) dalam penerapan APE Papan Flanel Pintar dengan tujuan untuk mengembangkan kemampuan bahasa dan kemampuan logika matematika atau kognitif mengalami peningkatan jika dibandingkan pada hasil siklus II rata-rata sebesar dari $73.2 \%$ pada siklus III menjadi $86.8 \%$

Selanjutnya data aktivitas anak-anak yang kurang relevan dengan kegiatan pembelajaran terlihat pada tabel 4 berikut ini:

Table 5. Data Aktivitas Anak-anak yang Kurang Relevan Dengan

Kegiatan Pembelajaran Pada Siklus Ke-III

\begin{tabular}{|c|c|c|c|c|}
\hline \multirow[b]{2}{*}{ No } & \multirow{2}{*}{\multicolumn{2}{|c|}{ Indikator }} & \multicolumn{2}{|c|}{ Ketercapaian } \\
\hline & & & $\begin{array}{c}\text { Kondisi } \\
\text { Awal }\end{array}$ & $\begin{array}{c}\text { Siklus } \\
\text { I }\end{array}$ \\
\hline 1. & $\begin{array}{l}\text { Masih } \\
\text { keinginan } \\
\text { sendiri }\end{array}$ & $\begin{array}{r}\text { punya } \\
\text { kerja }\end{array}$ & $30 \%$ & $15 \%$ \\
\hline 2. & $\begin{array}{l}\text { Masih } \\
\text { memunculk } \\
\text { egoisnya }\end{array}$ & n sifat & $24 \%$ & $12 \%$ \\
\hline
\end{tabular}

\begin{tabular}{|c|c|c|c|}
\hline \multirow[b]{2}{*}{ No } & \multirow[b]{2}{*}{ Indikator } & \multicolumn{2}{|c|}{ Ketercapaian } \\
\hline & & $\begin{array}{c}\text { Kondisi } \\
\text { Awal } \\
\end{array}$ & $\begin{array}{c}\text { Siklus } \\
\text { I }\end{array}$ \\
\hline 3. & $\begin{array}{lr}\text { Masih } & \text { punya } \\
\text { kegiatan di } & \text { luar } \\
\text { kelompok } & \\
\end{array}$ & $24 \%$ & $14 \%$ \\
\hline 4. & $\begin{array}{l}\text { Masih mengganggu } \\
\text { kegiatan di } \\
\text { dalam/luar kel. }\end{array}$ & $29 \%$ & $10 \%$ \\
\hline 5. & $\begin{array}{l}\text { Masih } \\
\text { menunjukkan tidak } \\
\text { mau ikut } \\
\text { melaporkan hasil }\end{array}$ & $27 \%$ & $15 \%$ \\
\hline
\end{tabular}


Jumlah

$26.8 \% \quad 13.2 \%$

Berdasarkan tabel 5 di atas terlihat bahwa aktivitas anak-anak yang kurang relevan dengan kegiatan pembelajaran pada siklus III mengalami penurunan dibandingkan dengan hasil pada siklus II yaitu sebesar (hasil siklus II $26.8 \%$ ) dan (hasil siklus III 13.2\%).

Berdasarkan tabel hasil penelitian di atas, terlihat anak-anak dapat bekerja sama, melakukan kegiatan belajar sesuai dengan tema saat itu serta dengan bimbingan guru pada penerapan APE papan flanel pintar dapat berjalan sesuai dengan RKH guru. Hasil perolehan kemampuan anak dari hasil unjuk kerja dan observasi guru diperoleh rerata perolehan skor dari kondisi awal mendapatkan $44.2 \%$ dan pada siklus I menjadi $57.8 \%$. Begitupun pada siklus II dalam penerapan APE Papan Flanel Pintar dengan tujuan untuk mengembangkan kemampuan bahasa dan kemampuan logika matematika atau kognitif mengalami peningkatan jika dibandingkan pada hasil siklus I ratarata sebesar dari $57.8 \%$ pada siklus II menjadi $73.2 \%$ dan pada penerapan APE Papan Flanel Pintar dengan tujuan untuk mengembangkan kemampuan bahasa dan kemampuan logika matematika atau kognitif mengalami peningkatan jika dibandingkan pada hasil siklus II rata-rata sebesar dari $73.2 \%$ pada siklus III menjadi $86.8 \%$.

Demikian juga kegiatan atau aktivitas yang kurang relevan dengan kegiata pembelajaran, hasil pengamatan menunjukkan terlihat bahwa aktivitas anak-anak yang kurang relevan dengan kegiatan pembelajaran pada siklus 1 mengalami penurunan dibandingkan dengan kondisi awal yaitu sebesar (kondisi awal 55.8\%) dan (hasil siklus I 42.2\%). Kemudian pada kegaiatan berikutnya bahwa aktivitas anak-anak yang kurang relevan dengan kegiatan pembelajaran pada siklus 1I mengalami penurunan dibandingkan dengan hasil pada siklus I yaitu sebesar (hasil siklus I $42.2 \%$ ) dan (hasil siklus II $26.8 \%$ ). Dan pada kegiatan terakhir pada siklus ke III terlihat bahwa aktivitas anak-anak yang kurang relevan dengan kegiatan pembelajaran mengalami penurunan dibandingkan dengan hasil pada siklus II yaitu sebesar (hasil siklus II $26.8 \%$ ) dan (hasil siklus III 13.2\%).

Melalui penerapan APE Papan Flanel Pintar, terlihat anak-anak dapat meningkatkan kerja sama, adanya signifikansi karena guru tidak dianggap sosok yang menakutkan tetapi sebagai fasilitator dan mitra untuk berbagi pengalaman sesuai dengan konsep creatif learning yaitu melalui discovery dan invention serta creativity and diversity sangat menonjol dalam penerapan APE ini.

Hasil perkembangan setelah kegiatan yang menggunakan APE papan flanel pintar ini diberikan dalam kegiatan pembelajaran pada siklusI, II dan III, terlihat adanya pengaruh pada perkembangan kemampuan berbahasa dan kemampuan logika matematika seperti: Anak mampu menyusun pola sesuai contoh hingga membuat pola sendiri, mengenal angka, konsep bilangan, konsep warna, konsep penjumlahan, mengenal dan membuat bentuk geometri.

\section{SIMPULAN}

Alat peraga edukatif memberikan kesempatan proses bersosialisasi kepada anak untuk mendapatkan dan memperkaya pengetahuan dengan menggunakan berbagai alat. Penggunaan alat peraga edukatif sebagai sumber pembelajaran haruslah disesuaikan dengan tingkat kebutuhan anak, karakteristik anak, tujuan pembelajaran serta minat anak. 
Setelah diajarkan pada anak-anak Taman Kanak-kanak, papan flanel pintar ini mampu meningkatkan kemampuan anak dalam berbagai indikator, seperti: mengenal suku kata, merangkai suku kata, berceritera, mengenal angka, konsep bilangan, menghubungkannya gambar dengan lambang bilangan, bentuk geometri, serta sekaligus meningkatkan kemampuan yang lain, seperti motorik halus, kemampuan berkomunikasi dan berinteraksi dengan orang lain, keberanian untuk memimpin, melakukan percobaan sederhana, membaca sederhana, dan sebagainya.

\section{DAFTAR PUSTAKA}

[1] Gardner, H. (1999). Intelligence reframed: multiple intelligences for the 21 century. New York: Basic Books.

[2] Gardner, H. (1993). Multiple intelligences: the theory in practice. New York: Basic Books.

[3] Sudono, A. (2000). Sumber belajar dan alat permainan. Jakarta: Gramedia. 